Article

\title{
British Naturalist Laura Roscoe Thornely (1860-1951), Taxonomist of Hydroids and Bryozoans
}

\author{
Dale R. Calder (iD
}

Citation: Calder, D.R. British Naturalist Laura Roscoe Thornely (1860-1951), Taxonomist of Hydroids and Bryozoans. Taxonomy 2021, 1 , 234-242. https://doi.org/10.3390/ taxonomy 1030017

Academic Editor: Cinzia Gravili

Received: 15 July 2021

Accepted: 5 August 2021

Published: 11 August 2021

Publisher's Note: MDPI stays neutral with regard to jurisdictional claims in published maps and institutional affiliations.

Copyright: (C) 2021 by the author. Licensee MDPI, Basel, Switzerland. This article is an open access article distributed under the terms and conditions of the Creative Commons Attribution (CC BY) license (https:// creativecommons.org/licenses/by/ $4.0 /)$.
Department of Natural History, Royal Ontario Museum, 100 Queen's Park, Toronto, ON M5S 2C6, Canada; dalec@rom.on.ca

\begin{abstract}
Laura Roscoe Thornely was born on 6 March 1860 in Blundellsands, Lancashire, England. On approaching age 30 , in the late 1880s, she became interested in the taxonomy of hydroids and bryozoans under Prof. W.A. Herdman at University College, Liverpool. Her studies during much of the 1890s were based largely on the relatively well-known fauna of the boreal northeastern North Atlantic Ocean. Around the turn of the century, however, her focus shifted to collections from the species-rich tropical Indo-West Pacific region, the hydroids and bryozoans of which were then little-known. The publications by Thornely on hydroids from the tropical western Pacific, from Sri Lanka, and from the Sudanese Red Sea, the most noteworthy of her works on the group, are still frequently cited. Concurrently, papers were published on the Bryozoa from Northern Ireland, the Indian Ocean, and Antarctica. Overall, she described 70 new species, with 26 of them based on hydroids and 44 on bryozoans; one hydroid species was assigned by her to a new genus. A person of affluent means, the motivation for her research appears to have been pure academic interest; she never held a university appointment or degree. Thornely died on 18 July 1951 at age 91 in Troutbeck, Westmorland, England.
\end{abstract}

Keywords: taxonomy; natural history; zoology; hydroids; bryozoans; biography; marine biology

\section{Introduction}

Laura Roscoe Thornely (1860-1951) established herself as a notable contributor to the knowledge of hydroids and bryozoans based largely on studies of species from the biologically rich tropical Indo-West Pacific region [1-9]. Earlier, she had undertaken studies of the two groups in boreal waters of the eastern North Atlantic Ocean [10-13]. That background experience, with a relatively well-known fauna, prepared her for studies on the decidedly understudied biota of the western Pacific and Indian oceans. Her final publication was on bryozoans from the Australian Antarctic Expedition of 1911-1914 [14].

The research by Thornely was carried out largely in the Zoological Laboratory at University College, Liverpool (later the University of Liverpool), England. Overseeing, facilitating, and encouraging her work at the university was Prof. (later Sir) William Abbott Herdman (1858-1924), D.Sc., F.R.S., F.R.S.E. Founded in 1881, the university opened in 1882 with Herdman as its first professor of natural history. Thornely's competence as a taxonomist of hydroids and bryozoans progressed during the following decade while working under his tutelage. Her publications on the two groups appeared over an interval of 30 years, with the first, on hydroids, appearing in 1894 [10] and the last, in 1924 [14], on bryozoans.

The objective of this study was to review the biological research of Laura Thornely. Included are synopses of the hydroid and bryozoan taxa named by her, together with the current status of each one. The publications by Thornely on both invertebrate groups are listed herein. Finally, it must be noted that Thornely's name has been misspelled in some publications as "Thorneley". 


\section{Materials and Methods}

Much of the information herein on Laura Roscoe Thornely has been extracted from Proceedings and Transactions of the Liverpool Biological Society (vols. 3-34), in addition to her papers on hydroids and bryozoans, cited above. References to her publications on hydroids were perused in Bedot [15,16] and Vervoort [17]; those on Bryozoa were found mostly on The Bryozoa Homepage [18]. Where known, the day or month a given paper by Thornely was published, as well as the year, is noted in the References section. Such information is of potential value in establishing priority of nomenclature. Nomenclaturally available genusand species-group names proposed by Thornely for Hydrozoa and Bryozoa, extracted from her publications, are listed in Tables 1 and 2. Included are the type localities of the species, as well as the type species of the single genus she established. Details on her family life were discovered at Geni.com [19]. Searches for a photograph of Thornely online, from persons at the Natural History Museum, London, from the Archives of the University of Liverpool, and from the Church of St. Michael and all Angels, Hawkshead, which she attended, were all unsuccessful.

\section{Personal Life}

Laura Roscoe Thornely was born in Blundellsands, Lancashire, England on 6 March 1860, the daughter of James "Jim" Thornely (1823-1898), solicitor and law clerk, and Laura "Poppy" (Roscoe) Thornely (1828-1919). Poppy was a granddaughter of William Roscoe (1753-1831), well-known banker, solicitor, historian, botanist, brief member of parliament, and noted early abolitionist of slavery. Laura was one of eight children in the Thornely family, with four brothers (Robert Roscoe, 1853-1865; Thomas, 1855-1949; James Lamport, 1865-1898; and William, 1869-1961) and three sisters (Mary, 1856-1943; Beatrice, 1858-1950; and Martha Grace, 1861-1955) [19]. James Thornely served for a time as trustee at the Gateacre Unitarian Chapel [20].

Laura Thornely became a dedicated student of natural history during the late 1880s as she approached age 30, and joined the Liverpool Biological Society as a member in 1889. She continued as an active member and supporter ("subscriber") of the society and its marine research stations for more than three decades, and was elected to its council during 1906-1911 (Proceedings and Transactions of the Liverpool Biological Society, Vols. 3-38). Considerable time from the late 1880s to the early 1910s was spent at the University of Liverpool. During that period, she established a reputation as a capable specialist of two taxonomically challenging groups of marine invertebrates, the hydroids and bryozoans. Evidence suggests, however, that she was never awarded an academic degree. Notably, the names and degrees of the council members of the Liverpool Biological Society were listed in issues of its Proceedings and Transactions. During the time she served on the council (1906-1911), her name appeared on those lists unaccompanied by any academic degrees, with only the title "Miss" being listed in vols. 21, 22, and 24. Even that title was deleted in vol. 25.

Her life was a comfortably affluent one, and she resided in a succession of desirable neighborhoods in England. After growing up at Blundellsands, Lancashire in the Greater Liverpool area, membership records of the Liverpool Biological Society reveal that Ms. Thornely lived at various times in other prosperous neighborhoods of the city, including Woolton Hill, Aigburth Hall Road, and Grassendale. After 1916, she moved north to the English countryside of Cumbria (then within Northumberland), where her residences are listed in the Proceedings and Transactions as the communities of Ambleside, Outgate, and, finally, Troutbeck. It was there that Laura Roscoe Thornely died on 18 July 1951 at the age of 91 . Her burial site, together with that of her mother, is listed as Burial Ground Section E, Grave E11 at the medieval Anglican Church of St. Michael and All Angels, Hawkshead, Ambleside, UK [21]. The inscription on her gravestone is as follows: 


\section{TO THE \\ DEAR MEMORY OF \\ LAURA THORNELY \\ WIFE OF \\ JAMES THORNELY \\ BORN APRIL 151828 \\ DIED OCTOBER 31919 \\ AND OF THEIR DAUGHTER \\ LAURA ROSCOE THORNELY \\ BORN MARCH 61860 \\ DIED JULY 181951}

Laura Thornely lived her life as an unmarried woman and left no descendants [19]. Her closest companion for many years was Eliza Foster Barham [22].

\section{Research in Natural History}

Laura Roscoe Thornely was particularly interested in hydroids and polyzoans (=bryozoans), invertebrate animals of different phyla often studied together and still referred to on occasion at that time as "zoophytes". Examinations of them were carried out at University College, Liverpool (later the University of Liverpool) under the supervision of Prof. William Abbott Herdman, Derby Chair of Natural History (1881-1919) and, later, Professor of Oceanography (1919-1920) at the university. She also collected and studied specimens at the marine research stations of the Liverpool Biological Society-first, at the Puffin Island Marine Biological Station (opened in 1887; closed in 1891), Anglesey, Wales [23], and afterwards, at its replacement, the Marine Biological Station at Port Erin, Isle of Man (opened in 1892; closed in 2006) [24].

From her base in the zoological laboratory of the university, Laura Thornely began her scientific studies in 1889 with research on hydroids collected at Puffin Island in the Irish Sea. Taxonomically, her interests thereafter appeared to be divided about equally between hydroids and bryozoans. Geographically, the focus of her work throughout much of the 1890s was on species inhabiting the eastern shores of the Irish Sea from the coast of Wales well to the north of Liverpool in England, as well as the offshore Isle of Man. Meanwhile, she also examined collections obtained during cruises in 1890 to the west coast of Ireland and in 1891 to Norway. Records of species assigned to both groups from her studies are scattered throughout the annual reports in Proceedings and Transactions of the Liverpool Biological Society (vols. 4-21). Although no new species were described in any of these early works, taxonomic knowledge about the fauna in the areas of study was expanded.

Thornely quickly gained competence in the taxonomy of both groups of invertebrates. The high respect that Prof. Herdman held for her and her work was apparent in an editorial note at the beginning of her first publication [10]:

"Miss L. R. Thornely ... has worked carefully through all the mass of material brought home by the various dredging and other collecting expeditions and has identified and mounted the species new and old. Miss Thornely's work has been carried on to some extent in the Zoological Laboratory of the College, where she has arranged the Hydroida and the Polyzoa in the "Local Collection", and she has also studied the living material at the Port Erin Biological Station. The success of her work will be seen from the numerous entries in the carefully compiled table of geographical distribution in the district which follows ..."

That initial publication of Thornely [10] dealt with hydroids identified from the socalled “L.M.B.C. district" (Liverpool Marine Biological Committee district), encompassing localities in Liverpool Bay including Liverpool, Puffin Island, and the Isle of Man. Some 30 species were added by her to the faunal list of the region, bringing the total to 87 species and one variety.

Short reports followed on collections from a cruise to Rockall Islet and Bank in the eastern North Atlantic Ocean aboard the S.S. Granuaile. The primary purpose of the 
cruise to this isolated site was the exploration of its geology, natural history, oceanography, and meteorology, although considerations were also given to the eventual establishment there of a meteorological station [25]. Once on-site, dredging was undertaken for benthic invertebrates, with 42 species and three varieties of bryozoans [11] and five species of hydroids [12] identified from the collections. Pioneer bryozoan specialist Eliza Catherine Jelly (1829-1914) assisted Thornely with the identification of some old, encrusted colonies of her specialty that were difficult to identify [11] (p. 80).

Throughout all of this early work, Thornely gained practical experience with both groups based on a relatively well-known fauna, namely that of the boreal eastern North Atlantic. Comprehensive taxonomic literature was available for the region at the time on both hydroids [26-29] and bryozoans [26,30]. Serendipitously, these studies were preparing her for future investigations on a poorly known biota half a world away. Her most challenging work on both hydroids and bryozoans was about to begin, with studies on the diverse fauna of the tropical Indo-West Pacific region. Within this region is an exceptionally species-rich area now known as the Coral Triangle [31], including the Philippines, Eastern Indonesia, Papua New Guinea, the Solomon Islands, and East Timor [32]. Some of her studies dealt with species from the triangle and adjacent areas.

The first of these investigations [1] was based on hydroids collected by Dr. Arthur Willey (1867-1942) in Blanche Bay, New Britain, the Loyalty Islands, British New Guinea Engineer group, and New Caledonia. Willey, then at the University of Cambridge, had gone to the Far East in 1894 to study the embryology of the pearly or chambered nautilus (Nautilus pompilius Linnaeus, 1758) [33]. While there between 1895 and 1897, he collected other invertebrates [34], including hydroids. In her paper, Thornely provided an account of 20 species, with 10 of them being new. Seven species mentioned only in her Introduction were identified merely to genus rank due to a lack of adequate materials.

That publication was followed by the last of her papers on British invertebrates [13]. It dealt with bryozoans collected from Northern Ireland in 1896, received from Robert Francis Scharff (1858-1934) of the National Museum of Ireland, Dublin. In it, Thornely identified 32 species from waters off Ballycastle and 33 from off Rathlin Island.

Specimens for her second study of Indo-West Pacific hydroids [2] had been collected by Dr. Herdman during investigations on the pearl oyster fishery in the Gulf of Mannar, Ceylon (Sri Lanka). The fishery had seen a decade of failure at the time, and studies were undertaken to investigate the resources and the reasons for its decline [35]. Surveys and collecting efforts were undertaken during 1902 in Sri Lankan waters of the gulf by Herdman and his assistant, James Hornell (1865-1949). Thornely identified one new genus and 43 species in the hydroid collection, with 13 of them being described as new to science. In a paper on bryozoans from the same investigation [3], 116 species were identified, with 16 of them plus a new variety being previously undescribed. Corrections and additions to these two studies appeared shortly after [4], along with the addition of another species of bryozoan.

Research on bryozoans of the Indian Ocean continued, with an examination of collections from the Indian Museum [5] and from the Percy Sladen Trust Expedition to the Indian Ocean in 1905 [7]. The collection from the Indian Museum included 81 species, with four of them considered new. It comprised material from the Indian Ocean, except for a few specimens from the Gaspar Strait, Indonesia, and the Strait of Malacca. The material from the Percy Sladen Trust Expedition included 106 species; nine were taken to be new, and four new varieties were distinguished and named.

Another opportunity to study little-known hydroids arose when a collection from a biological survey in 1904 to 1905 of the Sudanese Red Sea by Dr. Cyril Crossland (1878-1943) was assigned to her for identification [6]. Eighteen species were identified, with two of them described as new.

Her last paper on hydroids [8], and a companion work on Bryozoa [9], were based on collections from Okhamandal, India by James Hornell. The specimens for both reports were obtained, largely by dredging, from 09 December 1905 to 13 January 1906 [36]. The purpose of the overall study was to advance knowledge of the shallow water marine resources of 
Baroda (now part of the state of Gujarat), India, and to investigate species (such as pearl oysters) offering economic potential. In addition to the time normally required to assemble reports, the start of World War I delayed the publication of Part II of the report [37] (p. vii). In it, 17 species of hydroids were reported by Thornely [8], all of them previously described and most of them inhabitants of shallow waters. Of the 42 species reported in her paper on bryozoans [9], one new species and one new variety were described.

The final publication by Thornely [14] came from an examination of materials from the Australian Antarctic Expedition of 1911-1914. In it, 68 species of bryozoans were reported, with five being recognized as new. Illustrations of the new species in that work were mere sketches, and the descriptions of them were brief. The materials came largely from Commonwealth Bay, Antarctica, but also included specimens from Maria Island and Macquarie Island, Australia and the Auckland Islands, New Zealand. In addition to bryozoans, one species of Entoprocta was included in her report.

In all, Thornely described one new genus and 26 new species of hydroids (Table 1) and 44 new species of Bryozoa (Table 2). The types of some of these species, of both groups, are at the Natural History Museum in London and the Cambridge University Museum of Zoology. Several of the hydroids she described are well-known and widely distributed, including putatively circumglobal species such as Clytia linearis (Thornely, 1900) [1], C. brevithecata (Thornely, 1900) [1], better known at present as its junior synonym C. hummelincki (Leloup, 1935) [38], and Tridentata rugosissima (Thornely, 1900) [1].

Table 1. Names of Hydrozoa proposed by Laura Roscoe Thornely. Types exist at the Natural History Museum, London, UK for the species with an asterisk.

\begin{tabular}{ccc}
\hline Genus & Type Species & Type Fixation \\
\hline Clavactinia Thornely, $1904[2]$ & ${ }^{*}$ Clavactinia gallensis Thornely, 1904 [2] & by monotypy \\
\end{tabular}

\begin{tabular}{|c|c|c|}
\hline Species & Type Locality & Current Name \\
\hline Hydranthea australis Thornely, 1900 [1] & $\begin{array}{c}\text { Papua New Guinea: New Britain, Blanche } \\
\text { Bay, to } 73 \mathrm{~m}\end{array}$ & $\begin{array}{c}\text { Hydranthea australis Thornely, } 1900 \text { [1], } \\
\text { species inquirenda }\end{array}$ \\
\hline Ectopleura pacifica Thornely, 1900 [1] & $\begin{array}{c}\text { Papua New Guinea: New Britain, } \\
\text { Blanche Bay }\end{array}$ & Ectopleura viridis (Pictet, 1893) [39] \\
\hline Obelia linearis Thornely, 1900 [1] & $\begin{array}{l}\text { Papua New Guinea: New Britain, } \\
\text { Blanche Bay }\end{array}$ & Clytia linearis (Thornely, 1900) [1] \\
\hline Obelia delicatula Thornely, 1900 [1] & $\begin{array}{c}\text { Papua New Guinea: New Britain, Blanche } \\
\text { Bay, to } 73 \mathrm{~m}\end{array}$ & Clytia delicatula (Thornely, 1900) [1] \\
\hline Campanularia brevithecata [1] Thornely, 1900 & $\begin{array}{c}\text { Papua New Guinea: New Britain, } \\
\text { Blanche Bay }\end{array}$ & Clytia brevithecata (Thornely 1900) [1] \\
\hline Gonothyraea longicyatha Thornely, 1900 [1] & $\begin{array}{c}\text { Papua New Guinea: New Britain, Blanche } \\
\text { Bay, to } 91 \mathrm{~m}\end{array}$ & Obelia longicyatha (Thornely, 1900) [1] \\
\hline Sertularia pusilla Thornely, 1900 [1] & New Caledonia: Loyalty Islands, Lifu & $\begin{array}{l}\text { Sertularia pusilla Thornely, } 1900 \text { [1], } \\
\text { species inquirenda }\end{array}$ \\
\hline Sertularia littoralis Thornely, 1900 [1] & $\begin{array}{c}\text { New Caledonia: Loyalty Islands, } \\
\text { Lifu, littoral }\end{array}$ & $\begin{array}{c}\text { Sertularia littoralis Thornely, } 1900[1] \\
\text { species inquirenda }\end{array}$ \\
\hline Aglaophenia bellis Thornely, 1900 [1] & Papua New Guinea: Engineer Group & Pachyrhynchia cupressina (Lamouroux, 1816) [40] \\
\hline Plumularia compacta Thornely, 1900 [1] & New Caledonia & Plumularia strictocarpa Pictet, 1893 [38] \\
\hline * Corydendrium chevalense Thornely, 1904 [2] & Sri Lanka: Cheval Paar, 11-15 m & Oceania armata Kölliker, 1853 [41] \\
\hline * Podocoryne denhami Thornely, 1904 [2] & Sri Lanka: Palk Strait, 11-15 m & Hydractinia denhami (Thornely, 1904) [2] \\
\hline * Clavactinia gallensis Thornely, 1904 [2] & Sri Lanka: Galle Bay, $4 \mathrm{~m}$ & Clavactinia gallensis Thornely, 1904 [2] \\
\hline * Clytia geniculata Thornely, 1904 [2] & Sri Lanka: Cheval Paar, shallow & Clytia linearis (Thornely, 1900) [1] \\
\hline Campanularia corrugata Thornely, 1904 [2] & Sri Lanka: $\mathrm{N}$ of Cheval Paar, $13-18 \mathrm{~m}$ & Hebella corrugata (Thornely, 1904) [2] \\
\hline * Sertularia ligulata Thornely, 1904 [2] & Sri Lanka: Gulf of Mannar & Tridentata loculosa (Busk, 1852) [42] \\
\hline * Sertularia fissa Thornely, 1904 [2] & $\begin{array}{c}\text { Sri Lanka: Galle + off Mount Lavinia + off } \\
\text { Kaltura + Cheval Paar, 11-55 m }\end{array}$ & Dynamena fissa (Thornely, 1904) [2] \\
\hline * Sertularia rugosissima Thornely, 1904 [2] & Sri Lanka: Gulf of Mannar & Tridentata rugosissima (Thornely, 1904) [2] \\
\hline Thuiaria palans Thornely, 1904 [2] & Sri Lanka: Palk Bay, 13 m & Dynamena crisioides (Lamouroux 1824) [43] \\
\hline * Desmoscyphus palkensis Thornely, 1904 [2] & Sri Lanka: Palk Bay, $13 \mathrm{~m}$ & Dynamena moluccana (Pictet, 1893) [39] \\
\hline * Lytocarpus hornelli Thornely, 1904 [2] & $\begin{array}{c}\text { Sri Lanka: off Mount Lavinia + off Kaltura + } \\
\text { off Negombo }\end{array}$ & Taxella hornelli (Thornely, 1904) [2] \\
\hline * Lytocarpus fasciculatus Thornely, 1904 [2] & Sri Lanka: off Galle, along W coast & Monoserius pennarius (Linnaeus, 1758) [33] \\
\hline * Lytocarpus plumosus Thornely, 1904 [2] & Sri Lanka: Gulf of Mannar & ?Lytocarpia delicatula (Busk, 1852) [42] \\
\hline Ceratella crosslandi Thornely, 1908 [6] & Sudan: Port Sudan & Solanderia secunda (Inaba, 1892) [44] \\
\hline Lovenella corrugata Thornely, 1908 [6] & Sudan: Khor Dongola, 37 m & Lovenella corrugata Thornely, 1908 \\
\hline Perigonimus vagans Thornely, 1908 [6] & Sudan: Khor Shinab, 18-22 fm & ?Bougainvillia sp. \\
\hline
\end{tabular}


Table 2. Names of Bryozoa proposed by Laura Roscoe Thornely. Types exist at the Natural History Museum, London, UK for the species with an asterisk.

\begin{tabular}{|c|c|c|}
\hline Species & Type Locality & Current Name \\
\hline * Onychocella cucullata Thornely, 1905 [3] & Sri Lanka: Gulf of Mannar + off Trincomalee & Onychocella cucullata Thornely, 1905 [3] \\
\hline * Schizoporella avicularis Thornely, 1905 [3] & Sri Lanka: Gulf of Mannar & $\begin{array}{c}\text { Schizoporella avicularis Thornely, } 1905 \text { [3], } \\
\text { species inquirenda }\end{array}$ \\
\hline * Schizoporella viridis Thornely, 1905 [3] & Sri Lanka: Gulf of Mannar, coral banks & Stylopoma viride (Thornely, 1905) [3] \\
\hline Schizoporella collaris Thornely, 1905 [3] & Sri Lanka: off Mount Lavinia & $\begin{array}{c}\text { Schizoporella collaris Thornely, } 1905 \text { [3], } \\
\text { species inquirenda }\end{array}$ \\
\hline * Rhynchopora incisor Thornely, 1905 [3] & Sri Lanka: Gulf of Mannar + off Galle, 62 m & Drepanophora incisor (Thornely, 1905) [3] \\
\hline * Rhynchopora corrugata Thornely, 1905 [3] & Sri Lanka: Gulf of Mannar & Drepanophora corrugata (Thornely, 1905) [3] \\
\hline * Gemellipora protrusa Thornely, 1905 [3] & Sri Lanka: Gulf of Mannar, on "nullipore" balls & Characodoma protrusum (Thornely, 1905) [3] \\
\hline $\begin{array}{l}\text { * Lepralia purpurea Thornely, } 1905[3] \\
\text { * Lepralia multidentata Thornely, } 1905[3]\end{array}$ & $\begin{array}{c}\text { Sri Lanka: Gulf of Mannar } \\
\text { Sri Lanka: Gulf of Mannar + off Trincomalee }\end{array}$ & $\begin{array}{l}\text { Lepralia purpurea Thornely, 1905, species inquirenda [3] } \\
\text { Pleuromucrum multidentatum (Thornely, 1905) }\end{array}$ \\
\hline * Lepralia nitida Thornely, $1905^{1}[3]$ & $\begin{array}{l}\text { Sri Lanka: Gulf of Mannar } \\
\text { Sankal }\end{array}$ & $\begin{array}{l}\text { Pleuromucrum multidentatum (1hornely, 1905) [3] } \\
\text { Hippaliosina adhaerens (Thornely, 1906) [4] }\end{array}$ \\
\hline * Lepralia ceylonica Thornely, 1905 [3] & Sri Lanka: Gulf of Mannar & Thornelya ceylonica (Thornely, 1905) [3] \\
\hline${ }^{*}$ Lepralia fissa Thornely, $1905^{2}[3]$ & Sri Lanka: off Galle, deep water & Lepralia gallensis Thornely, 1906 [4], species inquirenda \\
\hline Lepralia triangula Thornely, 1905 [3] & Sri Lanka: Gulf of Mannar & Lepralia triangula Thornely, 1905 [3], species inquirenda \\
\hline * Smittia trispinosa var. protecta Thornely, 1905 [3] & Sri Lanka: Gulf of Mannar & Parasmittina protecta (Thornely, 1905) [3] \\
\hline *Phylactella spiralis Thornely, 1905 [3] & $\begin{array}{l}\text { Sri Lanka: Gulf of Mannar + off Mount Lavinia + off } \\
\text { Galle }\end{array}$ & Phylactella spiralis Thornely, 1905 [3] \\
\hline $\begin{array}{l}\text { * Retepora pocillum Thornely, } 1905[3] \\
\text { * Cellepora compacta Thornely, } 1905[3]\end{array}$ & $\begin{array}{l}\text { Sri Lanka: Gulf of Mannar } \\
\text { Sri Lanka: Gulf of Mannar }\end{array}$ & $\begin{array}{c}\text { Retepora pocillum Thornely, } 1905 \text { [3], species inquirenda } \\
\text { Rhynchozoon compactum (Thornely, 1905) [3] }\end{array}$ \\
\hline * Schizoporella inclusa Thornely, $1906^{3}[4]$ & Sri Lanka: Gulf of Mannar & Schizoporella avicularis Thornely, 1905 [3] \\
\hline Lepralia adhaerens Thornely, $1906^{1}$ [4] & Sri Lanka: Gulf of Mannar & Hippaliosina adhaerens (Thornely, 1906) [4] \\
\hline Lepralia gallensis Thornely, $1906^{2}[4]$ & Sri Lanka: off Galle, deep water & Lepralia gallensis Thornely, 1906 [4], species inquirenda \\
\hline * Scrupocellaria gaspari Thornely, 1907 [5] & $\begin{array}{l}\text { Indonesia: Gaspar Strait + Andaman Islands + Sri } \\
\text { Lanka: off Kirinda, } 58 \mathrm{~m}+\text { India: off Ganjam, } \\
51-64 \text { m }\end{array}$ & Licornaria gaspari (Thornely, 1907) [5] \\
\hline Canda pecten Thornely, 1907 [5] & $\begin{array}{c}\text { Myanmar: Cheduba, } 51-55 \mathrm{~m}+\mathrm{NE} \text { of Preparis } \\
\text { Island, } 75 \mathrm{~m}\end{array}$ & Canda pecten Thornely, 1907 [5] \\
\hline Mucronella formidabilis Thornely, 1907 [5] & Andaman Islands: NW of Sentinel Is., 457 m & $\begin{array}{l}\text { Mucronella formidabilis Thornely, } 1907 \text { [5], } \\
\text { species inquirenda }\end{array}$ \\
\hline * Mucronella maculata Thornely, 1907 [5] & India: Pedro Shoal, $46 \mathrm{~m}$ & $\begin{array}{c}\text { Mucronella maculata Thornely, } 1907 \text { [5], } \\
\text { species inquirenda }\end{array}$ \\
\hline Bugula neritina var. rubra Thornely, 1912 [7] & $\begin{array}{c}\text { Republic of the Seychelles: Amirante, } 62 \mathrm{~m}+ \\
\text { Providence Atoll, } 91 \mathrm{~m}\end{array}$ & $\begin{array}{c}\text { Bugula robusta MacGillivray, } 1869 \text { [45], but possibly a } \\
\text { valid species }\end{array}$ \\
\hline Bugula neritina var. tenuata Thornely, 1912 [7] & Mauritius: Cargados, $51 \mathrm{~m}$ & $\begin{array}{c}\text { Bugula robusta MacGillivray, } 1869 \text { [45], but possibly a } \\
\text { valid species }\end{array}$ \\
\hline $\begin{array}{l}\text { Bugula neritina var. ramosa Thornely, } 1912 \text { [7] } \\
\text { * Membraniporella magnifica Thornely, } 1912 \text { [7] }\end{array}$ & $\begin{array}{l}\text { Republic of the Seychelles: Amirante, } 42 \mathrm{~m} \\
\text { Mauritius: Cargados, } 55 \mathrm{~m}\end{array}$ & $\begin{array}{l}\text { Bugula ramosa Thornely, } 1912 \text { [7] } \\
\text { Klugerella magnifica (Thornely, 1912) [7] }\end{array}$ \\
\hline Cribrilina reticulata Thornely, 1912 [7] & Republic of the Seychelles: Providence, 91-143 m & $\begin{array}{l}\text { Cribrilina reticulata Thornely, } 1912 \text { [7], } \\
\text { species inquirenda }\end{array}$ \\
\hline Bifaxaria vagans Thornely, 1912 [7] & $\begin{array}{c}\text { Republic of the Seychelles: Seychelles, } 62-71 \mathrm{~m}+ \\
\text { Amirante, } 62 \mathrm{~m}\end{array}$ & Vix vagans (Thornely, 1912) [7] \\
\hline * Lepralia crassa Thornely, $1912^{4}$ [7] & Mauritius: Cargados, $55 \mathrm{~m}$ & Petraliella crassocirca Canu \& Bassler, 1929 [46] \\
\hline Lepralia marginata Thornely, $1912^{5}$ [7] & Republic of the Seychelles: Amirante, $229 \mathrm{~m}$ & Replacement name needed; species inquirenda \\
\hline * Lepralia bicornis Thornely, 1912 [7] & $\begin{array}{c}\text { Mauritius: Cargados, } 55 \text { m; Chagos Archipelago: } \\
\text { Salomon, } 137 \text { m }\end{array}$ & Lepralia bicornis Thornely, 1912 [7], species inquirenda \\
\hline Smittia glomerata Thornely, 1912 [7] & Mauritius: Cargados & Parasmittina glomerata (Thornely, 1912) [7] \\
\hline $\begin{array}{l}\text { Smittia ornata Thornely, } 1912 \text { [7] } \\
\text { Phylactella galeata Thornely, } 1912 \text { [7] }\end{array}$ & $\begin{array}{l}\text { Saya de Malha Bank, } 274 \mathrm{~m} \\
\text { Chagos Archipelago: Salomon, } 137 \mathrm{~m}\end{array}$ & $\begin{array}{l}\text { Parasmittina ornata (Thornely, 1912) [7] } \\
\text { Phylactella galeata Thornely, } 1912 \text { [7] }\end{array}$ \\
\hline Mucronella ellerii var. multiaviculariata Thornely, & Mauritius: Cargados, 37-55 m; Republic of the & Mucropetraliella multiaviculariata (Thornely, 1912) [7] \\
\hline Beania regularis Thornely, 1916 [9] & $\begin{array}{c}\text { Seychelles: Amirante, } 55 \mathrm{~m} \\
\text { India: Dwarka, Gujarat }\end{array}$ & Beania regularis Thornely, 1916 [9] \\
\hline Bugula neritina var. fastigiata Thornely, 1916 [9] & $\begin{array}{l}\text { India: Dwarka, 27-31 m + Chindi Reef, } 11-18 \mathrm{~m}+ \\
\text { Rupan Bandar + Kutchegad. All in Gujarat state }\end{array}$ & $\begin{array}{c}\text { Bugula neritina var. fastigiata Thornely, } 1916 \text { [9], } \\
\text { species inquirenda }\end{array}$ \\
\hline Membranipora elongata Thornely, $1924^{6}[14]$ & Antarctica: Commonwealth Bay, $46 \mathrm{~m}$ & Replacement name needed; species inquirenda \\
\hline Cellaria membranacea Thornely, 1924 [14] & Antarctica: Commonwealth Bay, $642 \mathrm{~m}$ & Swanomia membranacea (Thornely, 1924) [14] \\
\hline Mucronella coronata Thornely, 1924 [14] & Antarctica: Commonwealth Bay, $219 \mathrm{~m}$ & Aspidostoma coronatum (Thornely, 1924) [14] \\
\hline Aspidostoma obliquum Thornely, 1924 [14] & Antarctica: Commonwealth Bay, $201 \mathrm{~m}$ & Melicerita obliqua (Thornely, 1924) [14] \\
\hline Cellepora setosa Thornely, 1924 [14] & Antarctica: Commonwealth Bay, $201 \mathrm{~m}+219 \mathrm{~m}$ & Orthoporidra compacta (Waters, 1904) [47] \\
\hline
\end{tabular}

${ }^{1}$ Lepralia nitida Thornely, 1905 [3] is a permanently invalid junior primary homonym of Lepralia nitida Johnston, 1838 [48]. The binomen Lepralia adhaerens Thornely, 1906 [4], now Hippaliosina adhaerens (Thornely, 1906), was proposed as a replacement name for L. nitida Thornely, 1905. ${ }^{2}$ Lepralia fissa Thornely, 1905 [3] is a permanently invalid junior primary homonym of Lepralia fissa Busk, 1856 [49]. The binomen Lepralia gallensis Thornely, 1906 [4] was proposed as a replacement name for L. fissa Thornely, 1905. ${ }^{3}$ The binomen Schizoporella inclusa Thornely, 1906 [4], unnecessarily proposed as a replacement name for Schizoporella avicularis Thornely, 1905 [3], is a junior objective synonym of the latter. ${ }^{4}$ Lepralia crassa Thornely, 1912 [7] is a permanently invalid junior primary homonym of Lepralia crassa Ritter von Reuss, 1874 [50] and has been replaced by a synonym, Petraliella crassocirca Canu \& Bassler, 1929 [46] [51]. ${ }^{5}$ Lepralia marginata Thornely, 1912 [7] is a permanently invalid junior primary homonym of Lepralia marginata Calvet, 1909 [52]. A replacement name for the junior homonym is needed. ${ }^{6}$ Membranipora elongata Thornely, 1924 [14] is a permanently invalid junior primary homonym of Membranipora elongata d'Orbigny, 1853 [53]. A replacement name for the junior homonym is needed. Dating of the publication by d'Orbigny [53] follows Sherborn [54].

Thus, while Thornely provided new observations on the hydroid and bryozoan faunas of northwestern Europe, especially those of the Irish Sea area, her most significant contributions by far were to advance knowledge of the two groups in the biologically diverse but understudied Indo-West Pacific region. The descriptions of new taxa by her were relatively brief but generally adequate for identification. Her illustrations were also mostly satisfactory in comparison with those of her contemporaries, with the exception 
noted above [14]. Inasmuch as she never held an academic position, and her resources for scientific study must have been limited, her accomplishments are commendable.

The taxonomic investigations of Laura Roscoe Thornely have been underrecognized and underappreciated. Greater recognition and credit for her contributions to the knowledge of both hydroids and bryozoans, especially those of the tropical Indo-West Pacific, are warranted.

\section{Eponyms}

In addition to one genus, Thornelya Harmer, 1957 [55] (Bryozoa), six species have been named in honor of Laura Roscoe Thornely: Diphasia thornelyi Ritchie, 1909 [56] (Hydrozoa), Aglaophenia thornelyi Bedot, 1921 [57], as A. tornelyi (lapsus) (Hydrozoa), Schizoporella viridis var. thornelyi Livingstone, 1926 [58] (Bryozoa), Labioporella thornelyae Harmer, 1926 [59] (Bryozoa), Obelia thornelyi Nutting, 1927 [60] (Hydrozoa), and Calyptotheca thornelyae Dumont, 1981 [61] (Bryozoa). In founding the genus Thornelya, the distinguished British zoologist Sir Sidney Frederic Harmer, KBE, FRS (1862-1950) added the following tribute: "Named for Miss Thornely, whose specimens, presented to the British and Cambridge Museums, have been of great value to me in the preparation of this report" [54]. That generic name is currently taken to be valid.

Funding: This research was funded by United States National Science Foundation Program Partnerships for Enhancing Expertise in Taxonomy (PEET).

Acknowledgments: The help of Ray Lampert in locating information on the life of Laura Thornely is deeply appreciated and acknowledged. Sincere gratitude is also expressed to the six anonymous referees for their constructive reviews of the original manuscript. Particular thanks are likewise extended to Jo Klett, University Archivist at the University of Liverpool, Judith E. Winston, Smithsonian Marine Station, Fort Pierce, Florida, Gillian Mapstone, Natural History Museum, London, Mary E. Spencer Jones, Natural History Museum, London, Tony Hunter and Maureen Smith, World Museum, National Museums Liverpool, Rev'd Nick Hallam of the Church of St. Michael and All Angels, Hawkshead, UK, and former Ambassador Tom Macan, retired British diplomat and a congregant of the church, for responding to requests for help in the search for information on Thornely.

Conflicts of Interest: The author declares no conflict of interest.

\section{References}

1. Thornely, L.R. The Hydroid Zoophytes Collected by Dr. Willey in the Southern Seas. In Zoological Results Based on Material from New Britain, New Guinea, Loyalty Islands and Elsewhere, Collected during the Years 1895, 1896 and 1897; Willey, A., Ed.; Part IV; Cambridge University Press: Cambridge, UK, 1900; pp. 451-457, [Published May 1900, from the Title Page of Part IV of the report by A. Willey].

2. Thornely, L.R. Report on the Hydroida Collected by Professor Herdman, at Ceylon, in 1902. In Report to the Government of Ceylon on the Pearl Oyster Fisheries of the Gulf of Manaar, with Supplementary Reports upon the Marine Biology of Ceylon, by Other Naturalists; Herdman, W.A., Ed.; Part 2; Royal Society: London, UK, 1904; pp. 107-126, [Published sometime after July 1904; see Preface, p. vii].

3. Thornely, L.R. Report on the Polyzoa collected by Professor Herdman, at Ceylon, in 1902. In Report to the Government of Ceylon on the Pearl Oyster Fisheries of the Gulf of Manaar, with Supplementary Reports upon the Marine Biology of Ceylon, by Other Naturalists; Herdman, W.A., Ed.; Part 4; Royal Society: London, UK, 1905; pp. 107-130.

4. Thornely, L.R. Corrections and additions. In Report to the Government of Ceylon on the Pearl Oyster Fisheries of the Gulf of Manaar, with Supplementary Reports upon the Marine Biology of Ceylon, by Other Naturalists; Herdman, W.A., Ed.; Part 5; Royal Society: London, UK, 1906; pp. 449-450.

5. Thornely, L.R. Report on the marine Polyzoa in the collection of the Indian Museum. Rec. Indian Mus. 1907, 1, $179-196$.

6. Thornely, L.R. Reports on the marine biology of the Sudanese Red Sea.-X. Hydroida collected by Mr. C. Crossland from October 1904 to May 1905. J. Linn. Soc. Lond. Zool. 1908, 31, 80-85. [CrossRef]

7. Thornely, L.R. Reports of the Percy Sladen Trust Expedition to the Indian Ocean in 1905, under the leadership of Mr. J. Stanley Gardiner, M.A. Volume 4(1), No. X.-The marine Polyzoa of the Indian Ocean, from H.M.S. Skylark. Trans. Linn. Soc. London. 2nd Ser. Zool. 1912, 15, 137-157. [CrossRef]

8. Thornely, L.R. Report on the Hydroida collected by Mr. James Hornell at Okhamandal in Kattiawar in 1905-6. In Report to the Government of Baroda on the Marine Zoology of Okhamandal in Kattiawar; Hornell, J., Ed.; Part П; Williams \& Norgate: London, UK, 1916; pp. 147-150, [Published 1916, sometime after 10 July, see note p. x of the report]. 
9. Thornely, L.R. Report on the Polyzoa collected by Mr. James Hornell at Okhamandal in Kattiawar in 1905-6. In Report to the Government of Baroda on the Marine Zoology of Okhamandal in Kattiawar; Hornell, J., Ed.; Part П; Williams \& Norgate: London, UK, 1916; pp. 157-165, [Published 1916, sometime after 10 July; see note p. $x$ of the report].

10. Thornely, L.R. Supplementary report upon the hydroid zoophytes of the L.M.B.C. district. Proc. Trans. Liverpool Biol. Soc. 1894, 8, 140-147, [Paper read before the society on 09 February 1894; see pp. xi and 140 of the journal].

11. Thornely, L.R. On the Polyzoa. In Green, W.S., Notes on Rockall Island and Bank, with an account of the petrology of Rockall, and of its winds, currents, etc.: with reports on the ornithology, the invertebrate fauna of the bank, and on its previous history. Trans. Roy. Irish Acad. 1897, 31, 79-80, [Published August 1897; see Contents page iv].

12. Thornely, L.R. On the Hydrozoa. In Green, W.S., Notes on Rockall Island and Bank, with an account of the petrology of Rockall, and of its winds, currents, etc.: with reports on the ornithology, the invertebrate fauna of the bank, and on its previous history. Trans. Roy. Irish Acad. 1897, 31, 81, [Published August 1897; see Contents page iv].

13. Thornely, L.R. Polyzoa from Ballycastle and Rathlin Island. Irish Nat. 1902, 11, 161-162, [Published July 1902; see journal title header, p. 162].

14. Thornely, L.R. Polyzoa. Scientific reports of the Australian Antarctic Expedition 1911-1914. Ser. C. Zool. Bot. 1924, 6, 1-23.

15. Bedot, M. Matériaux pour servir à l’histoire des hydroïdes. $6^{\mathrm{e}}$ période (1891 à 1900). Rev. Suisse Zool. 1918, 26, 1-376.

16. Bedot, M. Matériaux pour servir à l'histoire des hydroïdes. $7^{e}$ période (1901 à 1910). Rev. Suisse Zool. 1925, 32, 1-657.

17. Vervoort, W. Bibliography of Leptolida (non-siphonophoran Hydrozoa, Cnidaria). Works published after 1910. Zool. Verh. 1995, $301,1-432$.

18. The Bryozoa Homepage. Available online: http:/ / bryozoa.net (accessed on 13 July 2021).

19. Geni.com. Available online: https:/ / www.geni.com/people/Laura-Thornely/6000000013622243290 (accessed on 13 July 2021 ).

20. Gateacre Society Walk Notes. Available online: http://gatsoc.atwebpages.com/history/walks/page119.html (accessed on 13 July 2021).

21. Hawkshead Benefice. Available online: https://www.hawksheadbenefice.co.uk/docs/hawks_inscriptions.pdf (accessed on 13 July 2021).

22. Ancestry.com. Available online: https://www.ancestry.com/genealogy/records/eliza-foster-barham-24-3mjtch?geo_a=r\&o_ iid=41015\&o_lid=41015\&o_sch=Web+Property (accessed on 13 July 2021).

23. Baker, R.A. The marine biological station on Puffin Island (Ynys Seiriol) and the work of the Liverpool Marine Biology Committee (1887-1892). Arch. Nat. Hist. 1994, 21, 217-224. [CrossRef] [PubMed]

24. Colman, J.S.; Bowers, A.B. The marine biological station of the University of Liverpool at Port Erin, Isle of Man: A new wing, and a new research vessel. J. Mar. Biol. Assoc. UK 1968, 48, 259-272. [CrossRef]

25. Green, W.S. Narrative of the cruise. In Green, W.S., Notes on Rockall Island and Bank, with an account of the petrology of Rockall, and of its winds, currents, etc.: with reports on the ornithology, the invertebrate fauna of the bank, and on its previous history. Trans. Roy. Irish Acad. 1897, 31, 39-47.

26. Johnston, G. A History of the British Zoophytes, 2nd ed.; John van Voorst: London, UK, 1847; 488p.

27. Hincks, T. A History of the British Hydroid Zoophytes; John van Voorst: London, UK, 1869; 338p.

28. Allman, G.J. Allman, G.J. A Monograph of the Gymnoblastic or Tubularian Hydroids. In Two Parts I-The Hydroida in General; Volume I; Ray Society: London, UK, 1871; Volume 46, 154p.

29. Allman, G.J. A Monograph of the Gymnoblastic or Tubularian Hydroids. In Conclusion of Part I, and Part II, Containing Descriptions of the Genera and Species of the Gymnoblastea; Volume II; Ray Society: London, UK, 1872; Volume 47, pp. 155-450.

30. Hincks, T. A history of the British marine Polyzoa; John van Voorst: London, UK, 1880; 601p.

31. Sanciangco, J.C.; Carpenter, K.E.; Etnoyer, P.J.; Moretzsohn, F. Habitat availability and heterogeneity and the Indo-Pacific Warm Pool as predictors of marine species richness in the tropical Indo-Pacific. PLoS ONE 2013, 8, e56245. [CrossRef]

32. Veron, J.E.N.; Devantier, L.M.; Turak, E.; Green, A.L.; Kininmonth, S.; Stafford-Smith, M.; Peterson, N. Delineating the Coral Triangle. Galaxea 2009, 11, 91-100. [CrossRef]

33. Linnaeus, C. Systema Naturæ, 10th ed.; Reformata. Laurentii Salvii: Holmiae, Sweden, 1758; 823p.

34. Kerr, J.K. Arthur Willey. 1867-1942. Obit. Not. Fellows Roy. Soc. 1943, 4, 394-410.

35. Herdman, W.A. Report to the Government of Ceylon on the Pearl Oyster Fisheries of the Gulf of Manaar, with Supplementary Reports upon the Marine Biology of Ceylon, by Other Naturalists; Part I; Royal Society: London, UK, 1903; 307p.

36. Hornell, J. Report to the Government of Baroda on the Marine Zoology of Okhamandal in Kattiawar; Part I; Williams \& Norgate: London, UK, 1909; 148p.

37. Hornell, J. Report to the Government of Baroda on the Marine Zoology of Okhamandal in Kattiawar; Part II; Williams \& Norgate: London, UK, 1916; 165p.

38. Leloup, E. Hydraires calyptoblastiques des Indes Occidentales. Mém. Mus. Roy. Hist. Nat. Belg. 2me Sér. 1935, 2, 1-73.

39. Pictet, C. Voyage de MM. M. Bedot et C. Pictet dans l'Archipel Malais. Étude sur les hydraires de la Baie d'Amboine. Rev. Suisse Zool. Ann. Mus. Hist. Nat. Genève 1893, 1, 1-64. [CrossRef]

40. Lamouroux, J.V.F. Histoire des Polypiers Coralligènes Flexibles, Vulgairement Nommés Zoophytes; F. Poisson: Caen, France, 1816; 560p. [CrossRef]

41. Kölliker, A. Über Scheibenquallen. In Bericht über Einige im Herbste 1852 in Messina Angestellte Vergleichend-Anatomische Untersuchungen. Z. Wiss. Zool. 1853, 4, 320-329. 
42. Busk, G. Appendix IV. An account of the Polyzoa, and sertularian zoophytes, collected in the voyage of the Rattlesnake, on the Coasts of Australia and the Louisiade Archipelago, \&c. In Narrative of the Voyage of H.M.S. Rattlesnake, Commanded by the Late Captain Owen Stanley, R.N., F.R.S. Ec., during the Years 1846-1850; Macgillivray, J., Ed.; T. \& W. Boone: London, UK, 1852; Volume 1, pp. 343-402.

43. Lamouroux, J.V.F. Description des Polypiers Flexibles. In Zoologie. Voyage Autour du Monde, Entrepris Par Ordre du Roi, Exécuté Sur les Corvettes de S.M. l'Uranie et la Physicienne, Pendant les Années 1817, 1818, 1819 et 1820; par M. Louis de Freycinet; Quoy, J.R.C., Gaimard, J.P., Eds.; Pillet Aîne: Paris, France, 1824; pp. 603-643.

44. Inaba, M. Soshu, Miura, Misaki ni oide edaru Hydroidea (Hydroidea obtained at Miura and Misaki in Soshu). Dobutsugaku Zasshi (Zool. Mag.) 1892, 4, 93-101.

45. MacGillivray, P.H. Descriptions of some new genera and species of Australian Polyzoa; to which is added a list of species found in Victoria. Trans. Proc. Roy. Soc. Vic. 1869, 9, 126-148.

46. Canu, F.; Bassler, R.S. Bryozoa of the Philippine region. Bull. US Nat. Mus. 1929, 100, 1-685.

47. Waters, A.W. Bryozoa from Franz-Josef Land, collected by the Jackson-Harmsworth Expedition, 1896-1897-Part II. Cyclostomata, Ctenostomata, and Endoprocta. J. Linn. Soc. Zool. 1904, 29, 161-184. [CrossRef]

48. Johnston, G. A History of the British Zoophyte; W.H. Lizars: Edinburgh, UK, 1838; 341p.

49. Busk, G. Zoophytology. Quart. J. Microscop. Sci. 1856, 4, 308-312.

50. Ritter von Reuss, A.E. Die fossilen Bryozoen des österreichisch-ungarischen Miocäns. Denkschr. Kaiserlich. Akad. Wiss. Math. Naturw. Classe 1874, 33, 141-190.

51. Tilbrook, K.J.; Cook, P.L. Petraliellidae Harmer, 1957 (Bryozoa: Cheilostomata) from Queensland, Australia. Syst. Biodiv. 2004, 2, 319-339. [CrossRef]

52. Calvet, L. Bryozoaires. In Expédition Antarctique Française (1903-1905), Commandée par le Dr Jean Charcot; Sciences Naturelles: Documents Scientifiques; Masson et Cie: Paris, France, 1909; pp. 1-49.

53. d'Orbigny, A. Paléontologie Française. In Terrains Crétacés. Bryozoaires; Masson: Paris, France, 1853; 1191p, [Dating of the relevant part of this work (p. 555, with an account of Membranipora elongata), follows Sherborn [54]. The publication date of an accompanying Atlas, with an illustration of the species (pl. 729, figs. 11, 12), is less certain].

54. Sherborn, C.D. On the dates of the "Paléontologie Française" of d'Orbigny. Geol. Mag. 1899, 6, 223-225, New ser., decade 4. [CrossRef]

55. Harmer, S.F. The Polyzoa of the Siboga Expedition. Part 4. Cheilostomata Ascophora II. Siboga-Exped. 1957, $28,641-1147$.

56. Ritchie, J. New species and varieties of Hydroida Thecata from the Andaman Islands. Ann. Mag. Nat. Hist. 1909, 3, 524-528.

57. Bedot, M. Notes systématiques sur les plumularides. ${ }^{\text {re }}$ Partie. Rev. Suisse Zool. 1921, 28, 311-356. [CrossRef]

58. Livingstone, A.A. Studies on Australian Bryozoa. No. 3. Rec. Austral. Mus. 1926, 15, 79-99. [CrossRef]

59. Harmer, S.F. The Polyzoa of the Siboga Expedition. Part 2. Cheilostomata Anasca. Siboga-Exped. 1926, 28, 181-501.

60. Nutting, C.C. Report on the Hydroida collected by the United States fisheries steamer "Albatross" in the Philippine region, 1907-1910. Bull. US Nat. Mus. 1927, 100, 195-242.

61. Dumont, J.P.C. A report on the cheilostome Bryozoa of the Sudanese Red Sea. J. Nat. Hist. 1981, 15, 623-637. [CrossRef] 